\section{Morphology and Irrigation Efficiency of Gaura lindheimeri Grown with Capacitance Sensor-controlled Irrigation}

\author{
Stephanie E. Burnett ${ }^{1}$ \\ Department of Plant, Soil, and Environmental Sciences, University of Maine, \\ 5722 Deering Hall, Orono, ME 04469
}

Marc W. van Iersel

Department of Horticulture, The University of Georgia, 1111 Miller Hall Plant Sciences Building, Athens, GA 30602

Additional index words. $\mathrm{ECH}_{2} \mathrm{O}$ probes, volumetric water content, leachate, greenhouse irrigation

Abstract. Gaura lindheimeri Engelm. \& Gray 'Siskiyou Pink' (gaura) and Phlox paniculata L. 'David' (garden phlox) were grown for 5 weeks in substrates irrigated at volumetric water contents $(\Theta)$ of $0.10,0.15,0.20,0.25,0.30,0.35,0.40$, or $0.45 \mathrm{~m}^{3} \cdot \mathrm{m}^{-3}$ using a capacitance sensor-controlled irrigation system. Volumetric water contents of the substrate measured by the capacitance sensors controlling irrigation were correlated with measurements with a separate handheld meter $\left(r^{2}=0.83\right)$ and with volumetric water content set points throughout the study $\left(r^{2}>0.98\right)$. Only 3.8 (at an irrigation set point of $\left.0.10 \mathrm{~m}^{3} \cdot \mathrm{m}^{-3}\right)$ to $53 \mathrm{~L}\left(0.45 \mathrm{~m}^{3} \cdot \mathrm{m}^{-3}\right)$ of water was used to irrigate gaura and phlox and 0 to $7.74 \mathrm{~L} \mathrm{of}$ this water leached out of the substrates. Significant leaching occurred only at $\Theta$ set points of 0.40 , or $0.45 \mathrm{~m}^{3} \cdot \mathrm{m}^{-3}$. Gaura had shorter and fewer branches and reduced dry weight when grown at lower volumetric water contents, but plants irrigated at set points above $0.25 \mathrm{~m}^{3} \cdot \mathrm{m}^{-3}$ were large enough to be marketable. Gaura may be grown with capacitance sensor-automated irrigation using water efficiently and minimizing or eliminating leachate and thus nonpoint source pollution.

Due to increasing population and limited water supplies, legislatures are beginning to request that agriculture, including commercial greenhouse growers, reduce water inputs. State and federal governments are also concerned about nonpoint source pollution from fertilizer runoff that contains nitrates and phosphorus (Lea-Cox and Ross, 2001). Because leachate volume correlates positively with irrigation volume, irrigating efficiently is a straightforward and inexpensive way to reduce leaching and runoff from container production (Bilderback, 2002). To improve irrigation efficiency (volume of water retained in substrate $\div$ volume of water applied), there are two basic questions that need to be answered: when should plants be irrigated and how much water should be applied?

Many growers use automated irrigation systems in greenhouses, including drip irrigation, boom systems, ebb and flood, and flood floor systems (Nelson, 2003). However, most growers "automate" their systems using

Received for publication 18 Sept. 2007. Accepted for publication 10 Oct. 2007.

Maine Agriculture and Forestry Experiment Station Publication \# 2977.

The Fred C. Gloeckner Foundation for funding this research project.

We thank Bradley Libby and Rachel Putnam and for providing advice and technical assistance.

${ }^{1}$ To whom reprint requests should be addressed; e-mailsburnett@maine.edu. timers or manually turn systems on and off in response to plant water use or changing environmental conditions. Ideally, growers would automate irrigation in response to changes in either substrate or plant water status. But, until recently, only tensiometers have been used to automate irrigation of container-grown ornamentals in floriculture production (Lieth and Burger, 1989). Although it is possible to automate irrigation using tensiometers, few growers currently do so because even "micro"-tensiometers are bulky and require routine maintenance. Growers must refill microtensiometers frequently, and they are easily dislodged from the substrate, which breaks capillarity and results in faulty readings. Other soil moisture sensors have been either too expensive or too large to install in the small containers typically used in greenhouse container crop production. However, new, small capacitance sensors $(\mathrm{EC}-5$; $\cong 5 \mathrm{~cm} \times 2 \mathrm{~cm}$; Decagon Devices, Pullman, WA) accurately estimate substrate volumetric water content $(\Theta=$ volume of water $\div$ volume of substrate; unpublished results). EC-5 sensors measure the dielectric permittivity of substrates. Since the dielectric constant of water is much greater than that of other substrate components, this measurement is used to estimate $\Theta$ (Decagon Devices, Inc., 2007). Sensor outputs are voltages, which are then converted to $\Theta$ using substrate-specific calibration equations. Nemali and van Iersel (2006) used similar probes to develop an automated irrigation system that irrigates plants when the substrate $\Theta$ drops below a predetermined set point. By maintaining a constant substrate $\Theta$, the irrigation system effectively replaces the water that is lost from the substrate by evaporation, transpiration, or leaching, assuring constant water supply for the plants. Essentially, this results in a plant-driven irrigation system; if the crop uses a lot of water, it automatically will receive more water than when the crop uses little water. Thus, the amount of water applied will depend on the environmental conditions as well as plant size and crop characteristics. Such an approach to irrigation provides an option for growers who want to automate irrigation using moisture sensors. Also, automated systems may allow growers to irrigate and use water and fertilizer more efficiently; if no excess water is applied, there will be little or no leaching of fertilizer salts.

To use these new, efficient irrigation systems, growers must have information regarding the water requirements of different crops. Unfortunately, much of the current information on ornamental plant water use is anecdotal and not quantitative. Recently, researchers have begun to examine ornamental plant water relations more closely through a variety of physiological measurements (Henson et al., 2006; Niu et al., 2006; Starman and Lombardini, 2006). Most experiments focus on screening crops to quantitatively determine which are the most drought-tolerant. This information, although valuable, does not reflect typical irrigation strategies in commercial greenhouses and would be most useful in landscape applications. Water requirements for many floricultural crops still remain unknown. For growers to use new, moisture sensorcontrolled irrigation systems in commercial production, more accurate, quantitative water requirements must be determined. Therefore, the primary purpose of this experiment was to determine how the morphology and water use efficiency of the popular herbaceous perennial, Gaura lindheimeri Engelm. \& Gray 'Siskiyou Pink' (gaura), changes when it is grown at a range of $\Theta$ in an automated system similar to that described by Nemali and van Iersel (2006). A second objective was to further test Nemali and van Iersel's (2006) irrigation system to determine how much leachate is produced when growing plants at a variety of $\Theta$ set points. Third, we wanted to quantify how irrigating gaura at different $\Theta$ set points affects growth and morphology. Gaura is a member of the Onagraceae family that is native to Texas and Louisiana and hardy to U.S. Department of Agriculture Zones 5 to 8 (Armitage, 1997). It is reported to be drought-tolerant (Finical et al., 2000).

\section{Materials and Methods}

Prevernalized, rooted gaura and garden phlox cuttings were obtained from a commercial grower (30 deep cells; Yoder Greenleaf, Lancaster, PA) and transplanted together into a commercial soilless substrate [Fafard 2P, 60\% peat: $40 \%$ perlite $(\mathrm{v} / \mathrm{v})$; 
Fafard, Agawam, MA] on opposite ends of 8.7-L aluminum foil-wrapped rectangular plastic containers $($ dimensions $=33 \times 20 \times$ $13 \mathrm{~cm}^{3}$ ) on 26 May 2006. Although two species were grown in each container, this article focuses on results for gaura because approximately one-third of the lower leaves of garden phlox had senesced, possibly due to environmental stress. The substrate in all containers was moistened evenly after planting. Gaura were pruned to a height of $\approx 7.5$ to $10 \mathrm{~cm}$ after planting. Plants were grown in a glass greenhouse. Holes were drilled into the bottoms of containers to allow for drainage, and containers were suspended above identical, intact containers to collect leachate.

Containers were irrigated using a control system similar to that described by Nemali and van Iersel (2006) using EC-5 rather than EC-10 sensors, because EC- 5 sensors are less sensitive to substrate electrical conductivity (EC) and temperature (Nemali et al., 2007). Briefly, one EC-5 capacitance sensor was buried horizontally in the center of each container $\approx 4 \mathrm{~cm}$ below the substrate surface. Sensor voltage output was measured every 20 min using a CR-10X datalogger (Campbell Scientific, Logan, UT). A substrate-specific calibration equation $(\Theta=$ voltage $\times 1.7647-$ $\left.0.4745, r^{2}=0.95\right)$ converted voltage measurements to $\Theta$. Beginning on 31 May 2006, one of 16 normally closed solenoid valves $(2.5 \mathrm{~cm}, 24$ VAC solenoid valves; Nelson Turf, Peoria, IL) automatically opened so that plants were irrigated using pressure-compensated dribble rings (internal diameter $\approx 13 \mathrm{~cm}$; Dramm, Manitowoc, WI) for $60 \mathrm{~s}$ when $\Theta$ dropped below the following set points as measured by the EC-5 probes: $0.10,0.15$, $0.20,0.25,0.30,0.35,0.40$, or $0.45 \mathrm{~m}^{3} \cdot \mathrm{m}^{-3}$. There were two drip rings in each container (one for each plant). The irrigation volume applied to each container per irrigation was not significantly different (average $=340 \mathrm{~mL}$ in $60 \mathrm{~s}$ ). Plants were fertilized with a continuous liquid feed at $50 \mathrm{mg} \cdot \mathrm{L}^{-1} \mathrm{~N}$ using MiracleGro Excel 15-5-15 Cal-Mag fertilizer $(15 \mathrm{~N}-2.2 \mathrm{P}-12.45 \mathrm{~K}$; The Scotts Company, Marysville, OH). Beginning 19 days after planting (DAP), the length of three randomly selected long branches of gaura was measured and averaged every week. At that time, the $\Theta$ and EC of the pore spaces was measured using a WET sensor (Delta T Devices, Cambridge, U.K.) in three different locations in the containers and these measurements were averaged. The $\mathrm{pH}$ of the substrate was also measured weekly in the center of the container using a handheld $\mathrm{pH}$ probe (IQ-150; IQ Scientific Instruments, Carlsbad, CA). All pH and EC measurements collected throughout the experiment were averaged before data analysis. Leachate volume (if any) was measured once a week beginning 19 DAP. The datalogger (Campbell Scientific) counted the number of times the plants were irrigated and recorded 1 (measured every $20 \mathrm{~min}$ and averaged every $2 \mathrm{~h}$ ) as measured by the EC-5 probes. The total irrigation volume applied after treatment initiation was calculated by multiplying the irrigation volume applied in a single, 60 -s irrigation cycle for each experimental unit by the number of irrigation events. On 13 July 2006, when plants were flowering and the largest plants were considered marketable, they were harvested. Leaf area (LI-3000A Portable Area Meter; LI-COR Biosciences, Lincoln, NE) and total branch number (branches greater than $2.5 \mathrm{~cm}$ long) were recorded. Shoot tissue (leaves, stems, and flowers) was dried in a drying room and dry weight was noted. Water use efficiency was calculated as a function of the applied irrigation water $\left(\mathrm{WUE}_{\mathrm{a}}=\right.$ shoot dry weight of gaura and phlox $\div$ irrigation volume applied) and irrigation water retained in the substrate $\left[\mathrm{WUE}_{\mathrm{r}}=\right.$ shoot dry weight of gaura and phlox $\div$ (applied irrigation volume - leachate)]. Water use efficiency was calculated for both species together because they were both planted in the same container and it was impossible to determine how much of the applied water each species used. Irrigation efficiency [(\{applied irrigation volume leachate volume $\} \div$ applied irrigation volume) $\times 100$ ] was also calculated to determine what fraction of the applied water was available to the plants. Plants were arranged in a randomized complete block design with two replications. The experimental unit was a single plant of each species in a container. Data were analyzed using general linear models in SAS (SAS Institute, Cary, NC). For comparisons of EC-5 and WET sensor measurements, all data after all treatments had reached their minimum $\Theta$ (26 DAP) were averaged and compared using regression analysis.

\section{Results and Discussion}

Substrate water content, irrigation, and water use efficiency. The daily average $\Theta$ was above the $\Theta$ set point throughout the experiment, but the daily average 1 fluctuated from day to day, especially for the lowest three set points $\left(0.10\right.$ to $0.20 \mathrm{~m}^{3} \cdot \mathrm{m}^{-3}$; Fig. 1$)$. Despite fluctuations in $\Theta$ at the three lower set points, there were clear differences in the average $\Theta$ among the treatments over the course of the experiment. The $\Theta$ averaged $0.17,0.21$, $0.25,0.28,0.32,0.37,0.42$, and $0.47 \mathrm{~m}^{3} \cdot \mathrm{m}^{-3}$ in treatments with irrigation set points of $0.10,0.15,0.20,0.25,0.30,0.35,0.40$, and $0.45 \mathrm{~m}^{3} \cdot \mathrm{m}^{-3}$ (averages represent measurements from 17 to 42 DAP). After each irrigation, $\Theta$ increased $0.13 \mathrm{~m}^{3} \cdot \mathrm{m}^{-3}$ at the lowest set point compared with $0.03 \mathrm{~m}^{3} \cdot \mathrm{m}^{-3}$ at the highest set point. Nemali and van Iersel (2006) similarly reported that $\Theta$ fluctuated more at lower set points, possibly as a result of lower substrate hydraulic conductivity when substrates have a lower $\Theta$. In this experiment, an average of $0.34 \mathrm{~L}$ of water was applied at each irrigation. Reducing the quantity of water applied when plants were irrigated and installing sensors near the bottom, not top of containers, results in smaller $\Theta$ fluctuations (Burnett and van Iersel, unpublished data; van Iersel et al., 2007).

EC-5 measurements were highly correlated to $\Theta$ set points and independent $\Theta$ measurements with a WET sensor throughout the experiment (Fig. 2A-B). Measurements with an independent sensor were used to validate the effectiveness of the EC-5 sensors,

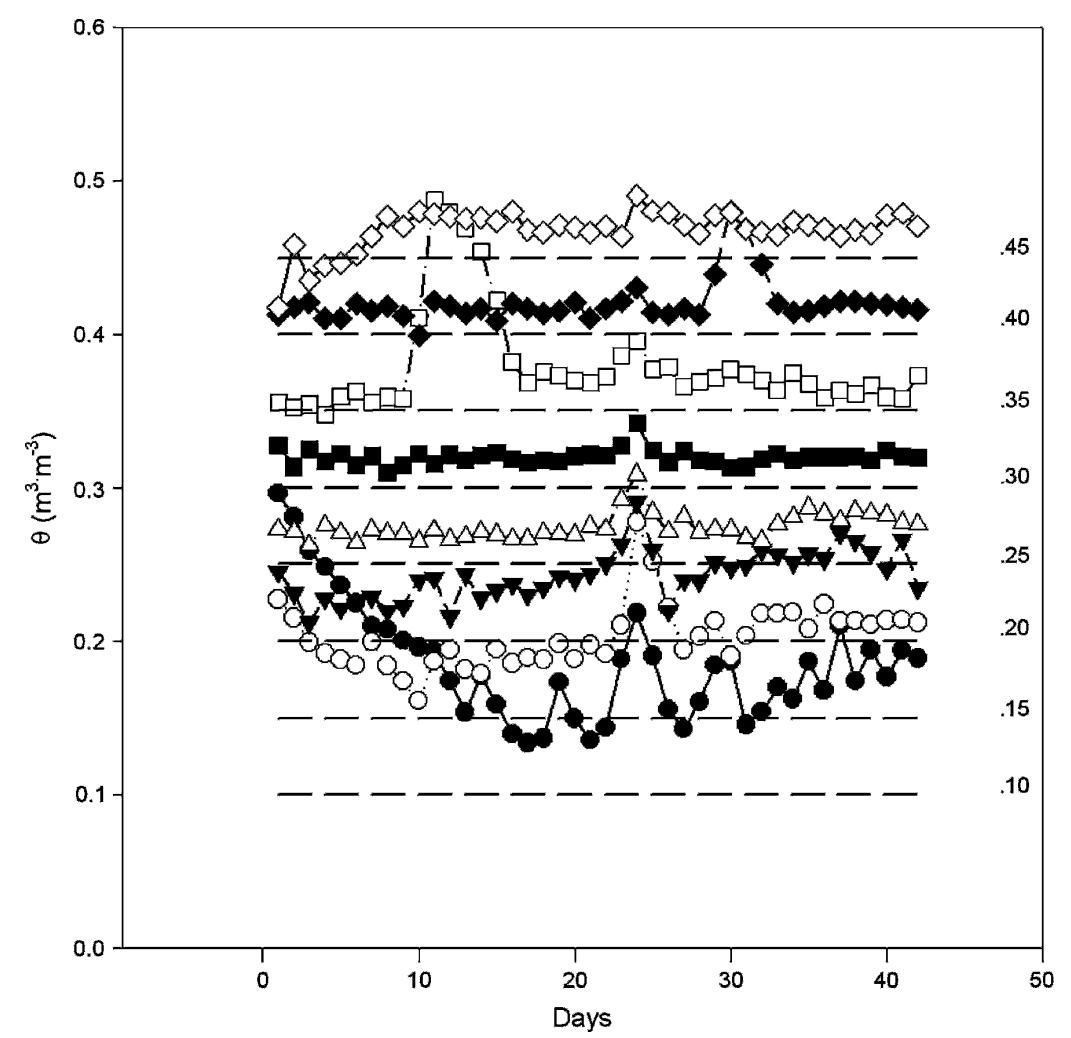

Fig. 1. Daily average EC-5 $\Theta$ measurements for the duration of the experiment. Substrates were irrigated as the $\Theta$ dropped below set points ranging from 0.10 to $0.45 \mathrm{~m}^{3} \cdot \mathrm{m}^{-3}$. $\Theta$ set points appear as dashed horizontal lines. Data points represent the averages of two blocks. 
which were used to automate irrigation. Correlations between measurements from both sensors indicate that the EC-5 sensors accurately measured $\Theta$. Nemali and van Iersel (2006) reported that measurements from similar, longer capacitance probes (EC-10; Decagon Devices) also correlated positively with $\Theta$ set points in their automated irrigation system. Changes in temperature, light levels, and relative humidity do not impact the ability of this irrigation system to maintain $\Theta$ above the set point (Nemali and van Iersel, 2006). While WET and EC-5 measurements were rarely identical, this is not surprising because measurements were taken in different locations within the substrate. In addition, EC-5 sensors were oriented horizontally in substrates, whereas the WET sensor was inserted vertically. Both sensors average measurements over the length of the probe, and vertical measurements would be affected by vertical moisture gradients in the substrate as a result of the impacts of gravity and evaporation on the water distribution in the substrates. Because both sensors are different lengths, they would measure different substrate volumes. Furthermore, EC-5 measurements were taken more frequently than WET sensor readings (504 times a week versus once a week for EC-5 and WET sensors, respectively).

Mean total applied irrigation volumes increased with increasing $\Theta$ set points and ranged from $3.8 \mathrm{~L}$ to $53 \mathrm{~L}$ per container (Fig. 3C). There was more between-replication variation at the two highest $\Theta$ set points ( 0.40 to $\left.0.45 \mathrm{~m}^{3} \cdot \mathrm{m}^{-3}\right)$, because these set points were close to the waterholding capacity of the medium and some of the irrigation water leached out of the containers. The difference in retained irrigation volume (applied irrigation volume - leachate volume) between the two replications was much smaller [differences of $3.64 \mathrm{~L}\left(0.40 \mathrm{~m}^{3} \cdot \mathrm{m}^{-3}\right)$ and $\left.0.95 \mathrm{~L}\left(0.45 \mathrm{~m}^{3} \cdot \mathrm{m}^{-3}\right)\right]$ than the difference in total irrigation volume [volumes of 32.72 $\mathrm{L}\left(0.40 \mathrm{~m}^{3} \cdot \mathrm{m}^{-3}\right)$ and $\left.67.44 \mathrm{~L}\left(0.45 \mathrm{~m}^{3} \cdot \mathrm{m}^{-3}\right)\right]$. The surface of substrates irrigated at those two set points always appeared moist, algal growth was observed on substrate surfaces, and there appeared to be more fungus gnats (Bradysia sp.) present. When data collected for those two set points were excluded from the data set, applied irrigation volumes increased quadratically with the $\Theta$ set point $\left(P=0.0041 ; R^{2}=0.83\right.$; range, 3.8 to $\left.29.8 \mathrm{~L}\right)$.

Containers irrigated when substrate $\Theta$ was below 0.10 to $0.30 \mathrm{~m}^{3} \cdot \mathrm{m}^{-3}$ did not leach any water or nutrients throughout the experiment. After 19 DAP, no leachate was collected from substrates irrigated at set points lower than 0.40 (irrigation efficiency $=100 \%$; Fig. 3D). However, early in the experiment, before all treatments had reached their $\Theta$ set points, a small volume $(0.01 \mathrm{~L})$ of leachate was collected from containers irrigated at $0.35 \mathrm{~m}^{3} \cdot \mathrm{m}^{-3}$. After 33 DAP, minimal $(13 \mathrm{~mL})$ to no leachate was collected in any of the treatments, including the two highest set points. Nineteen to 48 DAP, substrates irrigated at the two highest set points leached 5.03 and $0.87 \mathrm{~L}$ at 0.40 and 0.45 $\mathrm{m}^{3} \cdot \mathrm{m}^{-3}$, respectively, resulting in an irrigation
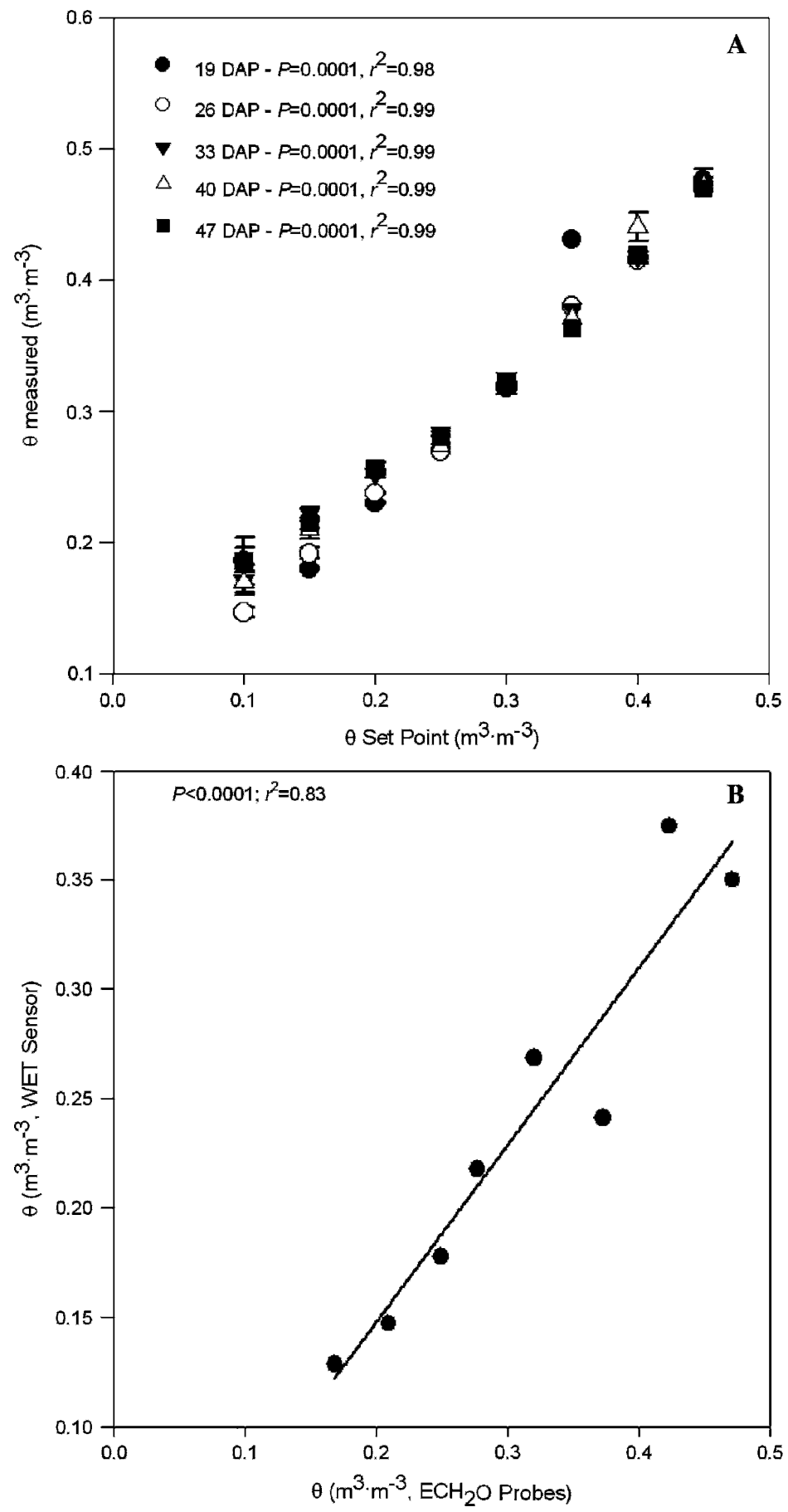

Fig. 2. (A) Correlation between substrate volumetric water content $\left(\Theta ; \mathrm{m}^{3} \cdot \mathrm{m}^{-3}\right)$ measured with EC-5 probes and $\Theta$ set points. EC-5 sensors measured $\Theta$ once every 20 min and data were averaged for each week beginning $12 \mathrm{~d}$ after planting (DAP). Data points are the mean of two replications with bars representing SES; SE bars are not shown for the $0.35 \mathrm{~m}^{3} \cdot \mathrm{m}^{-3}$ treatment because one replication of this treatment was considered an outlier. Other bars not visible are within the limit of the symbol. (B) Correlation between $\Theta$ measurements collected 504 times a week with EC-5 probes and measurements taken once a week with a WET sensor. Data points represent the average of all measurements collected from $26 \mathrm{~d}$ after planting until the end of the study. The regression line shows a significant correlation $[\Theta($ WET sensor $)=-0.014+0.810 \Theta($ EC-5 sensor $)]$.

efficiency of $89 \%\left(0.40 \mathrm{~m}^{3} \cdot \mathrm{m}^{-3}\right)$ or $99 \%(0.45$ $\mathrm{m}^{3} \cdot \mathrm{m}^{-3} ;$ Fig. 3D). It is unclear why the leachate fraction was higher for treatments in 0.40 compared with $0.45 \mathrm{~m}^{3} \cdot \mathrm{m}^{-3}$. If necessary, leaching could be further minimized by reducing the duration of each individual irrigation cycle, applying less water at a time. Cyclic irrigation, in which small volumes of water are applied frequently throughout the day, has been recommended as a best management practice for reducing water and nutrient runoff in container nurseries (Yeager et al., 1997). Fare et al. (1996) found that applying container nursery irrigation in cycles may reduce leachate volumes by approximately half.

Water use efficiency ( $\mathrm{WUE}_{\mathrm{a}}$ and $\mathrm{WUE}_{\mathrm{r}}$ ) decreased as plants were irrigated at higher $\Theta$ set points (Fig. 3A-B). Water use efficiency 

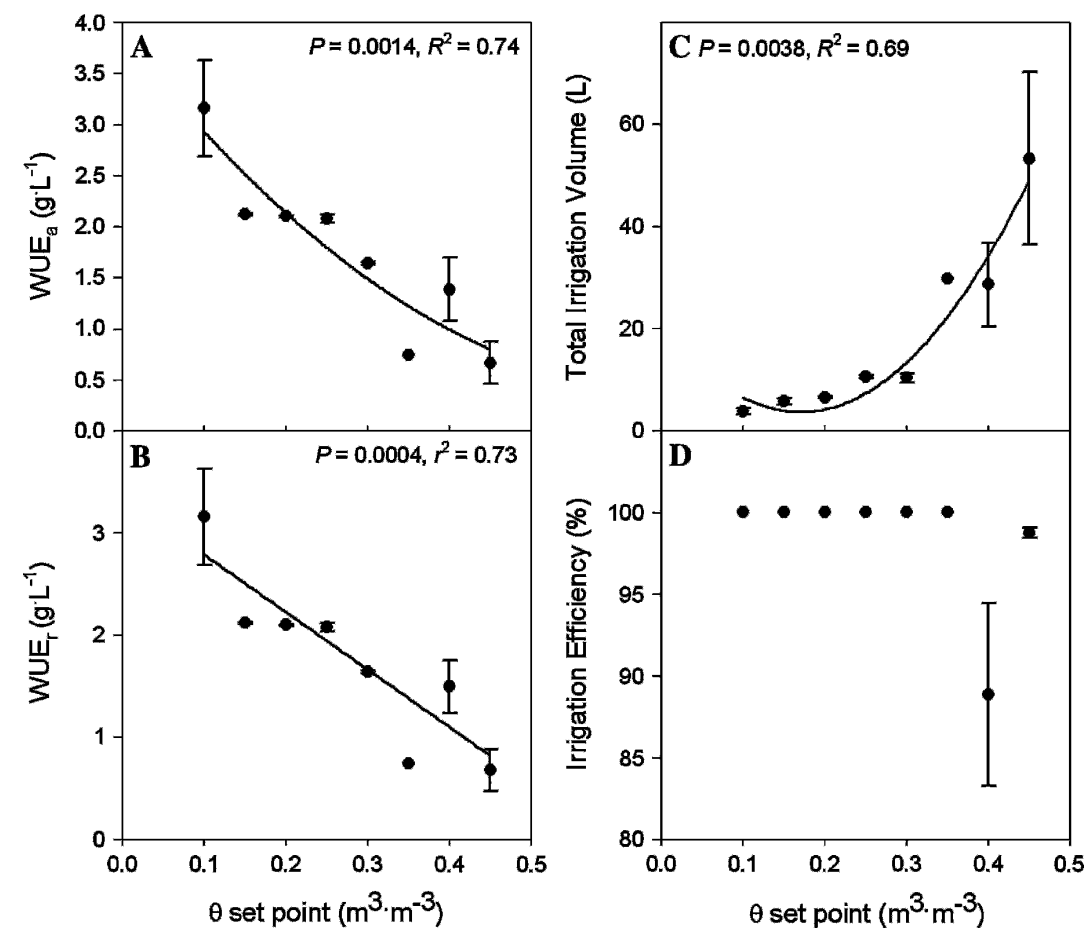

Fig. 3. (A) Water use efficiency $\left(\mathrm{WUE}_{\mathrm{a}}=\right.$ leaf, stem, and flower dry weight at harvest $\div$ total applied irrigation volume) of Gaura lindheimeri and Phlox paniculata decreased with increasing volumetric water content $\left(\mathrm{WUE}_{\mathrm{a}}=3.65\right.$ to $8.2 \Theta$ set point $+4.4 \Theta$ set point $\left.{ }^{2}\right)$. Data points were the mean of two replications with bars representing SES; SE bars are not shown for $0.35 \mathrm{~m}^{3} \cdot \mathrm{m}^{-3}$ because one replication of this treatment was considered an outlier. Other bars not visible are within the limit of the symbol. (B) Actual plant water use efficiency $\left(\mathrm{WUE}_{\mathrm{r}}=\right.$ leaf, stem, and flower dry weight at harvest $\div$ retained irrigation volume) of Gaura lindheimeri and Phlox paniculata. (C) Total irrigation volume applied to containers throughout the experiment at different volumetric water content $\left(\Theta ; \mathrm{m}^{3} \cdot \mathrm{m}^{-3}\right)$ set points. Data points are the mean of two replications with bars representing SES; SE bars are not shown for $0.35 \mathrm{~m}^{3} \cdot \mathrm{m}^{-3}$ because one replication of this treatment was considered an outlier. Other bars not visible are within the limit of the symbol. Irrigation data represent data for both Gaura lindheimeri and Phlox paniculata, because they were grown in the same containers. (D) Irrigation efficiency [(\{applied irrigation volume - leachate volume $\} \div$ applied irrigation volume $) \times 100$ ] for all treatments beginning $19 \mathrm{~d}$ after planting. Data points represent the average irrigation efficiency for both replications with bars representing SES. There are no SE bars for the lowest seven $\Theta$ set points because the irrigation efficiencies were identical for both blocks in those treatments.

varies with species and environmental factors (Kramer and Boyer, 1995). Because stomatal conductance $\left(g_{\mathrm{S}}\right)$ decreases with decreasing substrate water content, transpiration and thus water loss is generally reduced at lower substrate water contents (Taiz and Zeiger, 1998). A reduction in $g_{\mathrm{S}}$ normally decreases transpiration more than $\mathrm{CO}_{2}$ uptake by the leaf, so stomatal closure generally increases WUE while reducing the growth rate.

Substrate electrical conductivity and $\mathrm{pH}$. Electrical conductivity was higher in treatments irrigated at lower $\Theta$ set points throughout the experiment (Fig. 4A). This could be the result of higher leaching early during the growing period when plants were irrigated at higher $\Theta$. However, these results could also have simply been an artifact of the EC measurement method. The WET sensor measures the pore water conductivity, which is negatively correlated with $\Theta$, as a result of dilution of fertilizer ions in solution as $\Theta$ increases (Scoggins and van Iersel, 2006).

Substrate $\mathrm{pH}$ increased with increasing $\Theta$ throughout the experiment (Fig. 4B). Substrate $\mathrm{pH}$ may have been positively correlated with $\Theta$ because the irrigation water applied in this experiment is alkaline $(\mathrm{pH}, 8.1$; alkalin- ity, $1.18 \mathrm{meq} \cdot \mathrm{L}^{-1}$ ), and higher irrigation volumes may have resulted in higher substrate $\mathrm{pH}$. In addition, the fertilizer used has a potential basicity of $70 \mathrm{~g} \cdot \mathrm{kg}^{-1}$ (based on label information), which would result in a further increase in substrate $\mathrm{pH}$. However, previous research indicates that the actual solution $\mathrm{pH}$ of this fertilizer is acidic (van Iersel, 2003), which should have counteracted the impact of the water source. Further research in the future should closely examine the impact of zero-leach or low-leach irrigation systems on substrate EC and $\mathrm{pH}$ over time.

Plant growth and morphology. Stem length increased with increasing $\Theta$ set point throughout the experiment (Fig. 5A). Cell elongation is one of the most drought-sensitive plant processes (Hsiao, 1973) and increases with increasing turgor potential (Carpita and McCann, 2000; Cosgrove, 1997; Frensch, 1997; van Volkenburgh, 1999). Turgor potential typically decreases with decreasing water availability. Other floricultural crops such as annual salvia (Salvia splendens Sellow ex Roemer \& J.A. Schultes) and marigold (Tagetes patula L.) also are smaller when they are drought-stressed (Eakes et al., 1991; van Iersel and Nemali, 2004). Because drought reduces plant growth, it is used as a cultural control method for excessive plant growth (Bailey and Whipker, 1998). Growers desire shorter, more compact plants because they are less expensive to ship and generally easier to maintain in greenhouses than tall, leggy plants. However, accurately reducing elongation using drought stress is difficult because severe drought may kill plants or scorch leaf margins, thus reducing quality. By controlling irrigation based on $\Theta$, the severity of drought stress can be controlled. Moisture sensors can benefit growers who want to use drought as a growth retardant because they would see a predictable morphological response to irrigation over time. Also, moisture sensors may measure water contents as frequently as growers wish (every $20 \mathrm{~min}$ in this experiment), which would be impractical without automation when growers make irrigation decisions based on visual estimates of plant water needs or by using a timer.

It is important to note that drought does not just affect stem elongation, but also may reduce photosynthesis and respiration or negatively impact other physiological processes (Mohr and Schopfer, 1995). In this experiment, drought stress reduced leaf area (Fig. 5B); photosynthetic surface area is commonly reduced when plants are droughtstressed. Because photosynthesis provides energy for growth and maintenance of existing tissues, $\Theta$ may impact other components of morphology besides internode length. For this reason, it is important to understand species' responses to varying $\Theta$ levels on a crop-bycrop basis. Drought-stressed annual salvia (Salvia splendens F. Sellow. Ex Roem. \& Shult.) are both shorter and more compact (compactness = leaf area/height; Burnett et al., 2005). However, marigolds (Tagetes erecta. L.) grown at lower water contents are smaller but less compact (van Iersel and Nemali, 2004). Other plants, including lantana (Lantana camara L.) and cardinal flower (Lobelia cardinalis L.), do not exhibit morphological changes in response to drought (Starman and Lombardini, 2006). Although drought is a commonly used growth control method in commercial production, the effects of drought on morphology of many horticultural crops are not well quantified. In this experiment, shoot dry weight increased with increasing $\Theta$ set point, whereas the number of branches increased as the $\Theta$ increased from 0.10 to $0.25 \mathrm{~m}^{3} \cdot \mathrm{m}^{-3}$ with no consistent effects at higher $\Theta$ set points (Fig. 6A-B). Reductions in branch number are undesirable because plant canopies appear less dense and plants may be considered of lower quality. The dry weight per branch (total shoot dry weight $\div$ number of branches) was similar among the lowest levels of $\Theta$ set points $(0.10$ to $\left.0.35 \mathrm{~m}^{3} \cdot \mathrm{m}^{-3}\right)$, but much higher at $\Theta$ set points of 0.40 and $0.45 \mathrm{~m}^{3} \cdot \mathrm{m}^{-3}$ (Fig. 6C). This indicates more growth of individual branches at the highest $\Theta$ set points. It is vital for commercial greenhouse growers to be able to adequately predict plant growth responses to different substrate volumetric water contents. In the case of gaura, plants were shorter, but also 


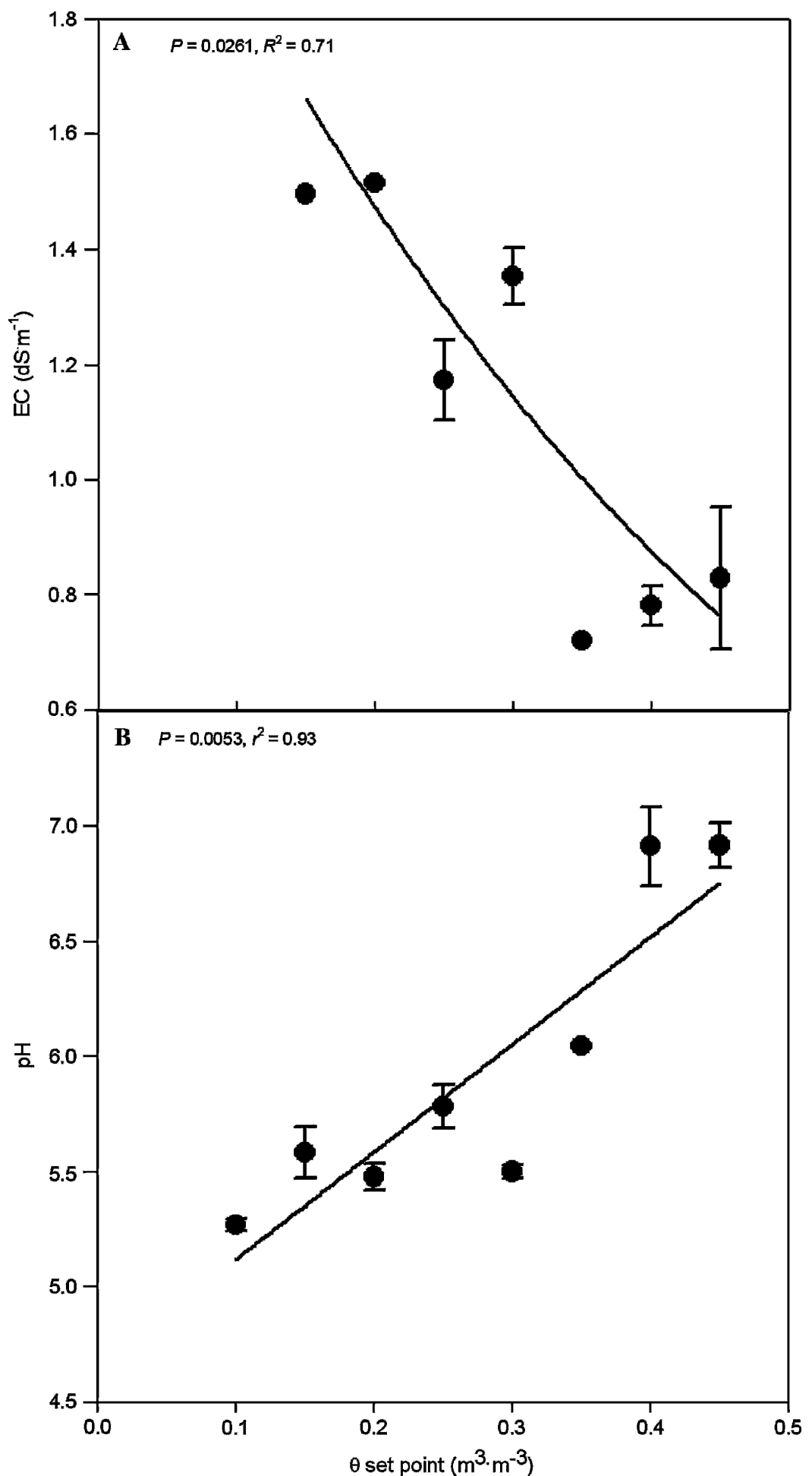

Fig. 4. (A) Electrical conductivity $\left(\mathrm{EC} ; \mathrm{dS} \cdot \mathrm{m}^{-1}\right)$ of the pore space solution of substrates irrigated at volumetric water content $(\Theta)$ set points ranging from 0.10 to $0.45 \mathrm{~m}^{3} \cdot \mathrm{m}^{-3}$. EC was measured in three different locations in each container weekly for 5 weeks beginning $19 \mathrm{~d}$ after planting (DAP). Data represent the averages of all measurements and replications with bars representing the sE between replications. (B) $\mathrm{pH}$ of substrates irrigated at the same $\Theta$ set points were measured using an IQ-150 pH probe as described previously.

smaller (fewer branches and lower dry weight $\div$ branch) when grown with lower $\Theta$ set points.

\section{Conclusions}

EC-5 moisture sensors measured the substrate volumetric water content reliably over the course of this experiment. Gaura to $0.35 \mathrm{~m}^{3} \cdot \mathrm{m}^{-3}$ ) resulted in little to no leaching. Plants had lower shoot dry weight and fewer and shorter branches when grown at lower $\Theta$. The largest impact on morphology seemed to be a reduction in both the number and length of branches when gaura was grown with $\Theta$ set points of 0.10 to $0.20 \mathrm{~m}^{3} \cdot \mathrm{m}^{-3}$. Gaura irrigated at $\Theta$ set points $0.25 \mathrm{~m}^{3} \cdot \mathrm{m}^{-3}$ or greater were similar in size and appearance.

\section{Literature Cited}

Armitage, A.M. 1997. Herbaceous perennial plants: A treatise on their identification, culture, and garden attributes. 2nd Ed. Stipes Publishing, L.L.C., Champaign, IL.

Bailey, D. and B. Whipker. 1998. Height control of commercial greenhouse flowers. N.C. Coop. Ext. Serv. Hort. Info. Lflt. 528.

Bilderback, T.E. 2002. Water management is key in reducing nutrient runoff from container nurseries. HortTechnology 12:541-544.

Burnett, S., P. Thomas, and M. van Iersel. 2005 Post-germination drenches with PEG-8000 reduce growth of salvia and marigolds. HortScience 40:675-679.

Carpita, N. and M. McCann. 2000. The cell wall, p. 52-108. In: Buchanan, B.B., W. Gruissem, and R.L. Jones (eds.). Biochemistry and molecular biology of plants. Amer. Soc. Plant Physiol., Rockville, MD.

Cosgrove, D.J. 1997. Relaxation in a high-stress environment: The molecular bases of extensible cell walls and cell enlargement. Plant Cel 9:1031-1041.

Decagon Devices, Inc. 2007. Theory. 9 Feb. 2007 $<$ http://www.decagon.com/echo/theory.html >.

Eakes, D.J., R.D. Wright, and J.R. Seiler. 1991. Moisture stress conditioning effects on Salvia splendens 'Bonfire'. J. Amer. Soc. Hort. Sci. 116:716-719.

Fare, D.C., C.H. Gilliam, G.J. Keever, and R.B Reed. 1996. Cyclic irrigation and media affect container leachate and ageratum growth. J. Environ. Hort. 14:17-21

Finical, L., A. Cameron, R.D. Heins, W. Carlson, and K. Kern. 2000. Forcing perennials crop by crop: Gaura lindheimeri 'Whirling Butterflies'. In: Greenhouse Grower and Michigan State University (eds.). Firing up perennials: The 2000 edition. Greenhouse Grower, Willoughby, OH.

Frensch, J. 1997. Primary responses of root and leaf elongation to water deficits in the atmosphere and soil solution. J. Expt. Bot. 48:985-999.

Henson, D.Y., S.E. Newman, and D.E. Hartley. 2006. Performance of selected herbaceous annual ornamentals grown at decreasing levels of irrigation. HortScience 41:1481-1486.

Hsiao, T.C. 1973. Plant responses to water stress. Ann. Rev. Plant Physiol. 24:519-570.

Kramer, P.J. and J.S. Boyer. 1995. Water relations of plants and soils. Academic Press, San Diego, CA.

Lea-Cox, J.D. and D.S. Ross. 2001. A review of the federal clean water act and the Maryland water quality improvement act: The rationale for developing a water and nutrient management planning process for container nursery and greenhouse operations. J. Environ. Hort. 19:226-229.

Lieth, J.H. and D.W. Burger. 1989. Growth of chrysanthemum using an irrigation system controlled by soil moisture tension. J. Amer. Soc. Hort. Sci. 114:387-392.

Mohr, H. and P. Schopfer. 1995. Plant physiology. Springer-Verlag, Berlin, Heidelberg, Germany.

Nelson, P.V. 2003. Greenhouse operation \& management. 6th Ed. Prentice Hall, Upper Saddle River, NJ. 


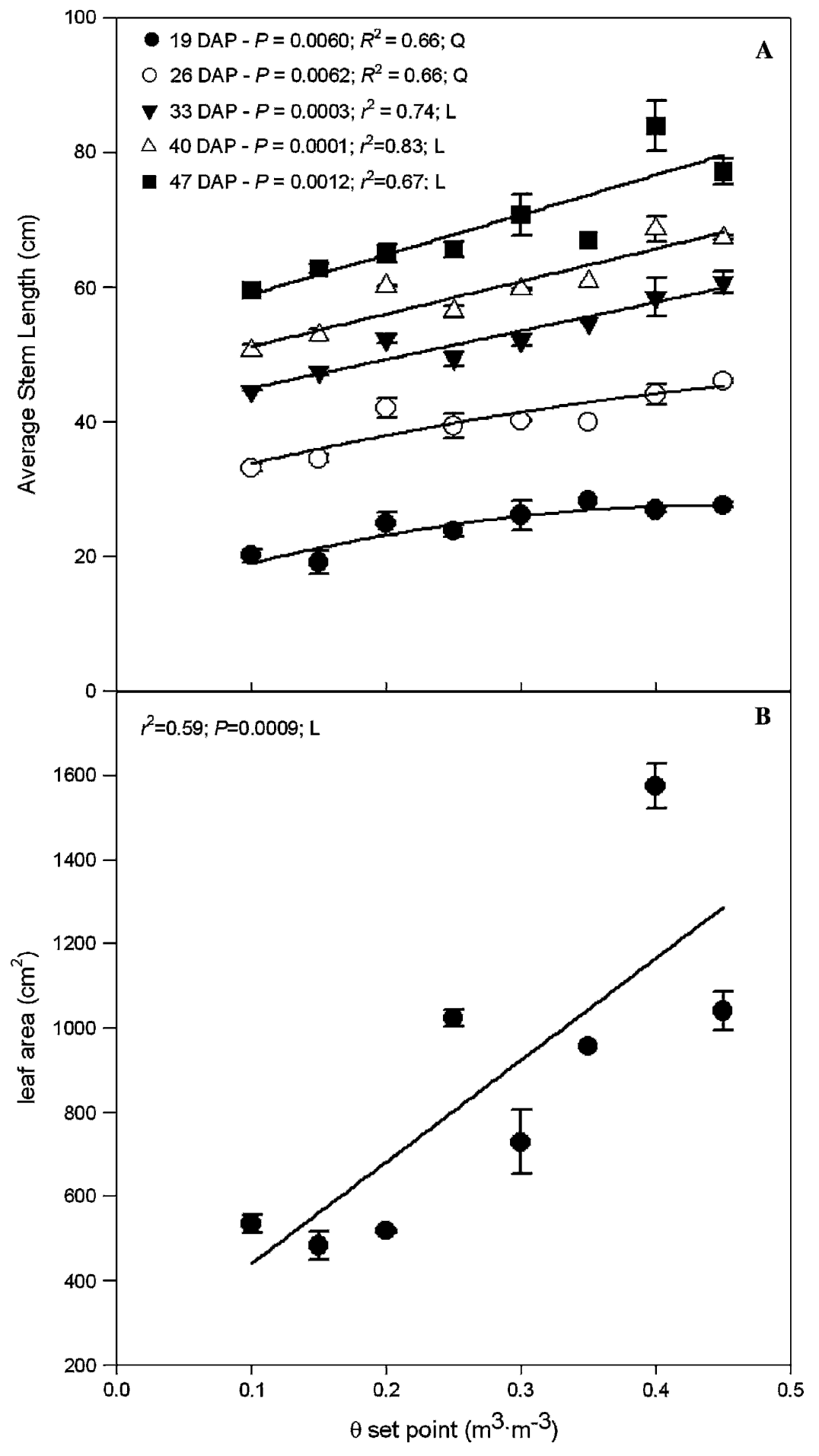

Fig. 5. Effects of volumetric water content set points on the average stem length of gaura at 19, 26, 33, 40, or $47 \mathrm{~d}$ after planting (DAP) (A) and gaura leaf area at 47 DAP (B). Regression curves show significant linear (L) or quadratic (Q) effects. Data points are the mean of two replications with bars representing sEs; SE bars are not shown for $0.35 \mathrm{~m}^{3} \cdot \mathrm{m}^{-3}$ because one replication of this treatment was considered an outlier.

Nemali, K. and M. van Iersel. 2006. An automated system for controlling drought stress and irrigation in potted plants. Sci. Hort. 110:292297.

Nemali, K.S., F. Montesano, S.K. Dove, and M.W. van Iersel. 2007. Calibration and performance of moisture sensors in soilless substrates: $\mathrm{ECH}_{2} \mathrm{O}$ and Theta probes. Sci. Hort. 111:227334.

Niu, G., D.S. Rodriguez, and Y. Wang. 2006. Impact of drought and temperature on growth and leaf gas exchange of six bedding plant

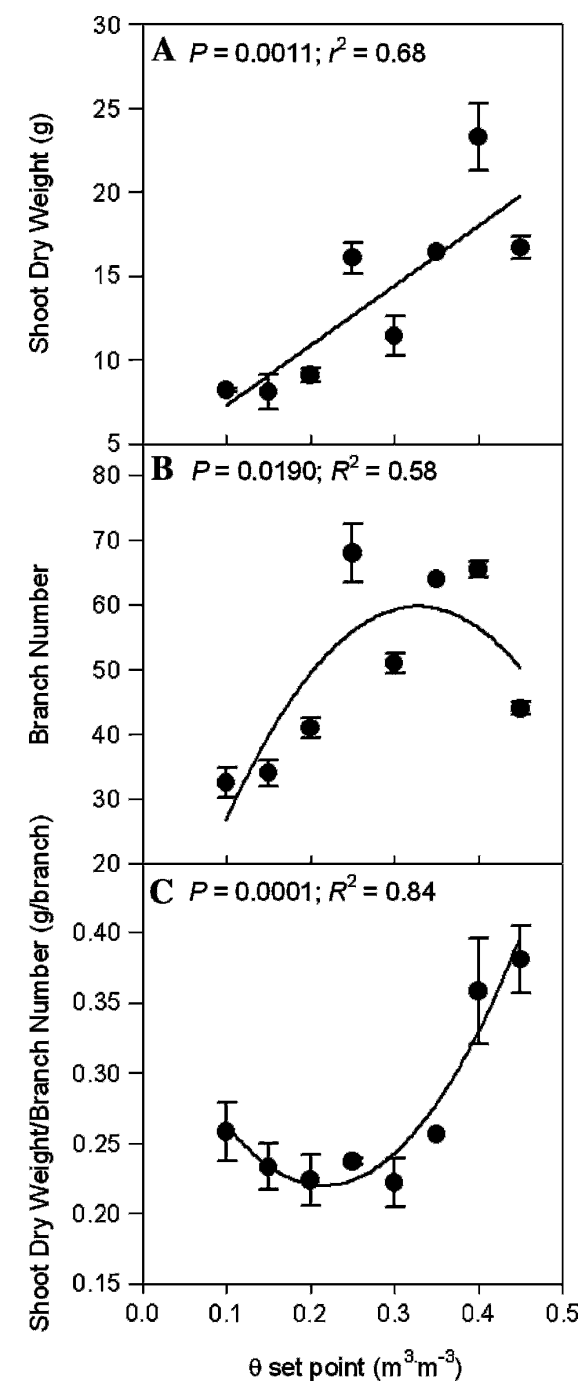

Fig. 6. Effects of volumetric water content set points $\left(\Theta ; \mathrm{m}^{3} \cdot \mathrm{m}^{-3}\right)$ on gaura shoot dry weight (A), number of branches greater than $2.5 \mathrm{~cm}$ long (B), and the shoot dry weight per branch (C) when plants were considered marketable (47 d after planting). Regression curves represent significant linear or quadratic effects. Data points are the mean of two replications with bars representing SES; SE bars are not shown for $0.35 \mathrm{~m}^{3} \cdot \mathrm{m}^{-3}$ because one replication of this treatment was considered an outlier.

Taiz, L. and E. Zeiger. 1998. Plant physiology. 2nd Ed. Sinauer Associates, Inc., Publishers, Sunderland, MA.

van Iersel, M. 2003. Actual pH and potential acidity of fertilizer solutions determine the $\mathrm{pH}$ of soilless mixes. Proc. Southern Nurs. Assn. Res. Conf. 48:538-541.

van Iersel, M.W., J.G. Kang, and S. Burnett. 2007. Making greenhouse irrigation more efficient: Effects of substrate water content on the growth $\&$ physiology of vinca (Catharanthus roseus). Proc. Southern Nurs. Assn. Res. Conf. (In press). species under different greenhouse conditions. HortScience 41:1408-1411.

Scoggins, H.L. and M.W. van Iersel. 2006. In situ probes for measurement of electrical conductivity of soilless substrates: Effects of temperature and substrate moisture content. HortScience 41:210-214.

Starman, T. and L. Lombardini. 2006. Growth, gas exchange, and chlorophyll flourescence of four ornamental herbaceous perennials during water deficit conditions. J. Amer. Soc. Hort. Sci. 131:469-475.

van Iersel, M.W. and K.S. Nemali. 2004. Drought stress can produce small, but not compact marigolds. HortScience 39:1298-1301.

van Volkenburgh, E. 1999. Leaf expansion-An integrating plant behavior. Plant Cell Environ. 22:1463-1473.

Yeager, T., D. Fare, C. Gilliam, A. Niemiera, T. Bilderback, and K. Tilt. 1997. Best management practices guide for producing container-grown plants. Southern Nurserymen's Assn., Marietta, GA. 